and his Ph.D. from Harvard in 1930. He was a Rhodes Scholar. Cole joined the faculty of the University of Washington in 1924 and served until he retired in 1967. He was the department's chairman from 1951 to 1959.

Kenneth was among the founders of the Pacific Northwest Political Science Association and was elected as its first president in 1948. At its first meeting in 1949 he delivered a memorable address on "Academic Freedom as a Civil Right" which was printed in the Western Political Quarterly. It was a landmark presidential address which challenged academics to probe the meaning of the concept. It provided the subject for panels at ensuing political science meetings.

Cole had great impact on a whole generation of graduate students who regarded his political theory seminars and critiques as brilliant. His questions on Ph.D. examinations and in classes were particularly penetrating and, during many of his years, political theory was regarded as the strongest field in the department.

Kenneth was a friend and admirer of Francis Coker. He brought many leading theorists and philosophers to the campus, thus enriching the opportunities of graduate students for first-hand meetings with Eastern scholars. The absence of easy air travel and sparse travel funds kept Seattle an outpost and these efforts during the first half of his tenure were especially rewarding for the department and its students.

Cole's father was a law professor, and Kenneth became a careful student of public law and augmented the department's work in that area. One University of Washington law professor characterized him as "an intellect without peer" on the campus.

Although Kenneth contributed articles to the leading journals he never published a book. For years he had a volume in progress but its contents were unknown. When this writer prodded him to bring out the book, he characteristically replied, "I'm afraid book reviewers will be as unkind to me as I have been in my book reviews."

In addition to his fine quality of mind, Kenneth was known for his wit and social graces. He and wife Alice could be counted upon to enliven parties. He enjoyed deep admiration, respect, and affection from his colleagues and his students. Many. students found him intimidating yet always fair, personally kind, and an inspiration. Faculty regarded him as a super critic and skeptic who could be, but was not always, caustic. His barbs were moderated by a marvelous sense of humor, and he was a great story teller. He and I served as witnesses in court only four days before his death, and his intellectual faculties were as keen as ever. I found my erstwhile colleague unduly modest - he was an outstanding political scientist.

Hugh A. Bone University of Washington

\section{Willard N. Hogan}

Willard N. Hogan was born in Dry Ridge, Kentucky, on March 26, 1909. On March 16, 1989, just short of what would have been his eightieth birthday, he died in Lincoln, Nebraska. He is survived by his wife, Hildur, of Lincoln, Nebraska; by his son, Edward, of Lincoln, Nebraska; by his daughters, Carolyn Rounds Boris of Wappinger Falls, New York, and Jeanette Tigh of Davis, California; by his son-in-law, Robert Boris of Wappinger Falls, New York; and by five grandchildren and three stepgrandchildren.

Although he spent the last quarter century of his life in Nebraska, Willard's educational and professional roots were in the state of his birth, Kentucky. It was there that he received his Bachelor of Arts degree from Transylvania College in 1930, and his Master of Arts degree from the University of Kentucky in 1934. After a year of study at the Brookings Institution (1935-36), he obtained his doctoral degree at the University of Chicago in 1939. During the period 1937-45-a period which partially overlapped his last years in graduate school-he held a number of research and administrative positions with the United States Government, mostly with the Federal Works Agency. In 1945, he was appointed to a position at Berea College in Kentucky, where he taught for the 
next four years and attained the rank of associate professor of history and political science. Thus, his first academic appointment was obtained in the same state where he had attended college and his first years of graduate school.

The next phase of his career was an extended and distinguished tour of duty as professor of political science at New York State University College at New Paltz, New York, from 1949 through 1963. During his years at New Paltz, he served as senior state member for the United $\mathrm{Na}$ tions Project at the Brookings Institution in 1952 and as Director of Information of the Center for the United Nations in 1949-56. It was during this period that he authored his book on International Conflict and Collective Security, published by the University of Kentucky Press in 1955. In addition, he co-authored two books, both published by McGraw-Hill, with Amry Vandenbosch: The United Nations (1955) and Toward World Order (1963).

In 1963, Willard came to Nebraska to fill a vacancy created by the retirement of Norman Hill. Here, as at New Paltz, he continued to be a vigorous and productive scholar. In 1967, the University of Nebraska Press published his work on Representative Government and European Integration. And he also contributed a number of articles and book reviews as he had during his New Paltz tour of duty. In March 1967, he was appointed chair of the department of political science and served in that capacity until 1969. This two-year span was marked by great flux. It was a time when many active and assertive young people were coming into the Department, when student unrest was mounting, when many social and educational innovations were being rushed through in a spirit of reaction against existing conventions. As chair, Willard kept the department from becoming hopelessly divided, made certain that unavoidable change would take place within a framework of order and civility, and maintained his good humor and courtesy at all times. In a very real sense, he shepherded our department through a time of troubles. It must have been an arduous period for him.

After completing his service as chair, Willard remained a very active and influen- tial protagonist in departmental affairs right up to the time of his retirement in 1974. During his years with the department, he was a member of the Mayor's Committee for United Nations Week in Lincoln and a member of the Council of the Midwest Political Science Association. He also established a reputation as an excellent and inspiring teacher. To cite a case in point, the daughter of one of his colleagues was motivated to switch from a linguistic to a legal career by her experience with the case study approach to international law-an experience to which she was first exposed in Willard's classes.

After Willard retired, he chose to remain in Lincoln, where he played an active role in the Agricultural Campus Neighborhood Association and pursued chess and other hobbies. The news of his death came as a shock to those of us who knew him as a gentle and erudite colleague in the turbulent days of the late 1960s and early 1970s. We shall long remember the contributions he made to our discipline and to our department. And we shall never forget his humanity and decency.

Raphael Zariski University of Nebraska-Lincoln

\section{Albert Berry Saye}

Albert Berry Saye, Professor Emeritus of the Department of Political Science, University of Georgia, died in an automobile accident on March 29, 1989. He was 76 years old. He is survived by his wife, Ruth Kendrick Saye.

He received his B.A. from the University of Georgia, Diplome de francaise from the University of Dijon, Ph.D. from Harvard University and the L.L.B. from the University of Georgia. He began his teaching career at the University of Georgia in 1934 and retired in 1980. He became an Alumni Foundation Distinguished Professor in 1957 and the Richard B. Russell Professor of Political Science in 1975. Dr. Saye was the recipient of many awards including the Michael Research Award, the Student Council Award, Blue Key, Alumni Service Award, and a Fulbright Award. Dr. Saye was a long-time advisor to the Demos- 